UDC: $579.61: 616.5$

\title{
DOMINANT MICROBIAL ASSOCIATIONS OF ORAL CAVITY AT PERIODONTITIS AND FEATURES OF THEIR SENSITIVITY TO ANTIBACTERIAL DRUGS
}

\author{
M. V. Kryvtsova@1*, Ye. Ya. Kostenko@2 \\ ${ }^{1}$ Uzhhorod National University, Biological Faculty, Department of Genetics, Plant Physiology \\ and Microbiology, 32, Voloshyn St., Uzhhorod 88000, Ukraine \\ ${ }^{2}$ Uzhhorod National University, Faculty of Dentistry, Department of Orthopaedic Dentistry \\ 16, Universytetska St., Uzhhorod 88000, Ukraine \\ *Corresponding author: e-mail: maryna.krivcova@uzhnu.edu.ua
}

Kryvtsova M. V., Kostenko Ye. Ya. Dominant microbial associations of oral cavat periodontitis and features of their sensitivity to antibacterial drugs. Studia Biologica, 2020: 14(1); 51-62 • DOI: https://doi.org/10.30970/sbi.1401.613

Opportunistic microorganisms play a significant role in the development of inflammatory diseases, including generalized periodontitis. The growing tendency towards the formation of antibiotic resistant microorganisms causes the relevance of monitoring the microorganisms' sensitivity to antimicrobial drugs and the development of new approaches to the antimicrobial therapy. The purpose of this work was to determine the dominant microbial associations of the oral cavity in the conditions of generalized periodontitis, to study their sensitivity to antibiotics, antiseptics and phytopreparations. The microbial associations' study at generalized periodontitis was performed by bacteriological monitoring of the pathological material from the foci of the inflammatory process. Determination of the isolates' antibiotic susceptibility to antiseptics and phytopreparations was carried out by the disc diffusion method, in the agar. As test culture, the following bacteria and yeast from the American Type Culture Collection were used: Candida albicans ATCC 885-653; Staphylococcus aureus ATCC 25923; Escherichia coli ATCC 25922; Enterococcus faecalis ATCC 29212; Streptococcus pyogenes ATCC 19615; and Pseudomonas aeruginosa ATCC ATCC 27853. We also used clinical strains of bacteria and yeasts (S. aureus, K. rhinoscleromatis, H. alvei, E. coli, S. pyogenes, S. pneumoniae, C. albicans, C. glabrata isolated from the oral cavities of patients suffering from the inflammatory periodontium. We selected clinical strains with multiple resistance to antibiotics. The results of studies have shown that the opportunistic microorganisms dominated

(c) 2020 M. V. Kryvtsova et al.; Published by the Ivan Franko National University of Lviv on behalf of Біологічні Студії / Studia Biologica. This is an Open Access article distributed under the terms of the Creative Commons Attribution License (http://www.budapestopenaccessinitiative.org/ and Creative Commons Attribution 4.0 License), which permits unrestricted reuse, distribution, and reproduction in any medium, provided the original work is properly cited.

ISSN 1996-4536 (print) • ISSN 2311-0783 (on-line) • Біологічні Студії / Studia Biologica • 2020 • Том 14/№1 • С. 51-62 
in $100 \%$ of cases within the oral cavity microbiota in patients with generalized periodontitis. The most pronounced clinical symptoms of the disease and recurrent inflammation were observed with the persistence of the Staphylococcus genus bacteria association with the Enterobacteriaceae family bacteria and Pseudomonas bacteria genera, microscopic Candida genus fungi in the oral cavity. It was found that the fluoroquinolones and cefoperazone/sulbactam were the most effective against the isolates. Among the commercial preparations, Sangviritrin showed the most expressive antimicrobial activity and its antibacterial effect was registered on the clinical isolates of $S$. aureus. It is worth noting that the Sangviritrin showed the antimicrobial effect against an extra antibioticresistant isolates resistant to all phytopreparations and disinfectants used in the test. A high antimicrobial activity of Decasanum and Sangviritrin against the multi-antibiotic resistant strains, most by against Gram-positive bacteria, was established. The established regularities determine the relevance of the antibiotic therapy taking into account the antibiotic susceptibility of the inflammatory process pathogens and the development of a comprehensive approach for correction of the opportunistic microbiota at generalized periodontitis.

Keywords: antibiotic resistant isolates, opportunistic microorganisms, antibacterial activity, oral cavity microbiota

\section{INTRODUCTION}

The inflammatory diseases of the periodontal tissues, including generalized parononitis, are multifactorial diseases, in whose etiology, the microbial factor occupies the key position [2, 6, 13]. At the first stages of the periodontitis formation, significant disorders of the periodontal tissues local immunity and anaerobic Gram-negative Actinobacillus actinomycetemcomitans, Porphyromonas gingivalis, Prevotella intermedia and Tannerella forsythensis bacteria play an important role, being involved in the periodontal pockets formation, the connective tissue destruction, and the alveolar bone resorption. The inflammatory infiltrate formation is accompanied by a variety of immunopathologies.

Along with this, the cause of complications and recurrences of the inflammatory periodontal diseasse is the microbial cenosis restructuring and the opportunistic microorganisms domination within the microbial associations of the oral cavity. The colonization of the mucous membrane with transient and allochthonic microbiota representatives, frequently manifesting multiple resistance to antibiotics, leads to a permanent recurrence and chronic inflammatory process [4, 15]. Due to this particular reason, some authors consider periodontitis that is an opportunistic infection, accompanied by the presence of opportunistic and pathogenic bacteria in the oral cavity $[7,12,13]$. It is also established that bacteria causing inflammatory periodontal processes can be a separate risk factor for cardiovascular, cerebrovascular diseases and premature delivery $[8,11]$. That is why, antibacterial drugs are widely used in treatment of the periodontal tissues $[4,13,14]$.

At the same time, the ever-increasing trend towards the formation of the antibiotic resistance, especially among the representatives of the opportunistic microbiota, including that in the biofilm $[8,18]$, requires new approaches to both local and systemic treatment. Under such conditions, a permanent monitoring of the poly-antibiotic resistant

ISSN 1996-4536 (print) • ISSN 2311-0783 (on-line) • Біологічні Студії / Studia Biologica • 2020 • Том 14/№1 • C. 51-62 
microorganisms circulation, the study of their sensitivity to antibacterial drugs, the development of new integrated approaches and means for the oral microbiocenosis correction in the inflammatory process is relevant.

The purpose of the present study was to determine the dominant microbial associations of the oral cavity at generalized periodontitis, to clarify their sensitivity to antibiotics, antiseptics and phytopreparations.

\section{MATERIALS AND METHODS}

The isolates that caused periodontal inflammatory processes were isolated on the basis of the Dental Polyclinic at Uzhhorod National University; the antimicrobial activity was studied at the Microbiology Laboratory at the Department of Genetics, Plant Physiology and Microbiology, Uzhhorod National University.

As the test culture, the following bacteria and fungi from the American Type Culture Collection were used: Candida albicans ATCC 885-653; Staphylococcus aureus ATCC 25923; Escherichia coli ATCC 25922; Enterococcus faecalis ATCC 29212; Streptococcus pyogenes ATCC 19615. We also used clinical strains of bacteria and fungi (S. aureus, $K$. rhinoscleromatis, $H$. alvei, E. coli, S. pyogenes, S. pneumoniae, C. albicans, C. glabrata isolated from the oral cavities of patients suffering from inflammatory periodontitis. We have selected clinical strains with multiple resistance to antibiotics.

The following domestically produced commercial phytopreparations were used in the study: Sangviritrin (DKP Pharmaceutical Factory LLC, Zhytomyr), Tinctura Salviae ("Vishpha", Lviv), Rotocanum (State Enterprise "Experimental Plant of Medicines IBONH NAS of Ukraine", Kyiv, Ukraine), Tinctura Eucalypti (Fitofarm JSC, Bakhmut), Chlorophyllipt (Arterium, Halychpharm JSC, Lviv), Tinctura Menthae (Viola Pharmaceutical Factory, Zaporizhia.), and Mint mouth rinse (Herbaria, Hungary).

The following disinfectants were used: Decasanum (Yuria-Pharm LTD, Kyiv, Ukraine), Dioxydine (Farmak JSC, Kyiv, Ukraine) Chlorhexidine (Monfarm JSC, Monastyryshche, Ukraine), Metronidazole (Yuria-Pharm Kyiv, LTD., Ukraine), Miramistin (PrAT "Darnitsa Farmaceutical Company”, Kyiv, LTD., Ukraine).

We examined 180 patients diagnosticated for generalized periodontitis; the control group composed of 50 persons without such diagnosis. The biological material was collected from the mucous membrane of the inflammatory site using a sterile transport system (a test tube with gel and an applicator for biological fluids produced by FLmedical (Italy). The material was plated according to Gold on nutrient media: Sabourund Dextrose Agar, HiCrome ${ }^{\mathrm{TM}}$ Candida Differential Agar (Himedia) for the cultivation of microscopic fungi, hemolytic microflora, namely, the Streptococcus and Neisseria genera bacteria on the blood agar, Enterobacteriaceae genera bacteria - on Endo and Ploskirev agar (Farmaktiv, Ukraine), the Staphylococcus genus bacteria - on Mannitol Salt Agar (Biolif-Italia), Enterococci were identified with Bile esculin agar (Biolif-Italia )

We identified the bacteria and fungi based on macromorphology, micromorphology, physiological and biochemical tests using ENTEROtest, STREPTO-test, STAPHYLOtest produced by Erba Lachema.

The antibiotic sensitivity of bacteria and microscopic fungi was identified by the disc diffusion method according to the accepted procedure (Order No. 167 of the $\mathrm{MOH}$ of Ukraine dated 05/04/2007; EUCAST (European Committee on Antimicrobial Susceptibility Testing).

ISSN 1996-4536 (print) • ISSN 2311-0783 (on-line) • Біологічні Студії / Studia Biologica • 2020 • Том 14/№1 • C. 51-62 
The bacteria isolates were screened for a susceptibility to the following antibiotics: ampicillin $(10 \mu \mathrm{g})$, amoxicillin-clavulanic acid $(20 / 10 \mu \mathrm{g})$, cefazolin $(30 \mu \mathrm{g})$, ceftriaxone $(30 \mu \mathrm{g})$, imipenem $(10 \mu \mathrm{g})$, meropenem $(10 \mu \mathrm{g})$, cefuroxime $(50 \mu \mathrm{g})$, cefoperazone/ sulbactam $(75 \mu \mathrm{g})$, ciprofloxacin $(5 \mu \mathrm{g})$, levofloxacin $(5 \mu \mathrm{g})$, gatifloxacin $(5 \mu \mathrm{g})$, norfloxacin $(10 \mu \mathrm{g})$, ofloxacin $(1 \mu \mathrm{g})$, lomefloxacin $(10 \mu \mathrm{g})$, tetracycline $(30 \mu \mathrm{g})$, erytromycin $(15 \mu \mathrm{g})$, azitromycin $(15 \mu \mathrm{g})$, clarithromycin $(15 \mu \mathrm{g})$. The fungi isolates were screened for susceptibility to the following antibiotics: (in $6 \mathrm{~mm}$ diameter wells) with nystatin $(50 \mu \mathrm{g})$, itroconazole $(10 \mu \mathrm{g})$, fluconazole $(25 \mu \mathrm{g})$, ketoconazole $(10 \mu \mathrm{g})$, voriconazole $(1 \mu \mathrm{g})$, klotrimazole $(10 \mu \mathrm{g})$, miconazole $(50 \mu \mathrm{g})$.

The microorganisms' sensitivity to plant-based materials and disinfectants was determined by the standard agar diffusion test (with $8 \mathrm{~mm}$ diameter wells) [3]. The antibacterial properties was carried out according to the following criteria: absence of a growth retardation zone of $10 \mathrm{~mm}$, indicating that the microorganisms are not sensitive to the sample inserted into the well; that of $10-15 \mathrm{~mm}$ indicates a weak sensitivity; $15-25 \mathrm{~mm}$ means sensitivity; more than $25 \mathrm{~mm}$ - high sensitivity.

The data obtained were expressed as mean \pm standard deviation (SD) of three measurements. The Tukey's test was applied for comparisons of mean values, differences were considered reliable at $p<0.05$. Statistical analysis and comparisons among the means were carried out using Microsoft Excel 2013. The parameters calculated alongside with the basic variation were: average and standard deviation; minimum and maximum coefficients of variation; and the inhibition zones size frequency.

\section{RESULTS AND DISCUSSION}

The total of 389 opportunistic microorganisms strains were isolated from 180 patients with persistent inflammatory process at generalized periodontitis. The Staphylococcus genus bacteria were isolated from the inflammatory site in $73 \%(131 / 180)$ cases and were represented by four species: S. aureus, S. haemolyticus, S. saprophyticus, S. epidermidis. In 53 patients $S$. aureus was isolated, 20 of them being methicillin-resistant. In 44 patients, S. haemolyticus was isolated.

The Streptococcus genus bacteria were isolated in $37.2 \%(67 / 180)$ of the patients with generalized paradontitis belonging to the S. pyogenes, S. agalactiae, S. viridans, S. mutans, S. pneumoniae species. The Enterococccus genus bacteria were isolated in $30 \%$ (54/180) cases. In $38.9 \%$ (70/180) of the patients, the Enterobacteriaceae family bacteria were isolated whose species diversity was represented by the following species: Escherichia coli, Enterobacter cloacae, Citrobacter freundii, Klebsiella rhinoskleromatis, Hafnia alvei.

It was reported that in patients with the most acute symptoms of the disease, the following associations of microorganisms were isolated: $S$. aureus $+E$. faecalis; S. epidermidis + E. cloacea; S. haemolyticus + E. cloaceae; S. aureus + K. rhinoskleromatis; S. saprophyticus + C. glabrata + E. cloaceae; S. saprophyticus + C. freundii; S. aureus $+H$. alvei + C. albicans.

The total of 45 microscopic fungi strains of the Candida genus were isolated, 38 of them belonging to $C$. albicans, 5 strains - to C. glabrata, $2-C$. cruzei. In patients with generalized periodontitis, the following representatives of indigenous microbiota were isolated: nonpathogenic streptococci S. sanguis, S. mitis, S. salivarius. In $57 \%$ cases the Lactobacillus genus bacteria were isolated.

ISSN 1996-4536 (print) • ISSN 2311-0783 (on-line) • Біологічні Студії / Studia Biologica • 2020 • Том 14/№1 • С. 51-62 
By studying the microbiota of mouth cavity in control group patients, we ascertained presence of the nonpathogenic Streptococcus spp.; lactobacilli were identified in $91.5 \%$ of the reviewed material and only in $57 \%$ of patients suffering from the periodontitis. The microbiota of the healthy gum tissues was characterized by a low population level of microbial populations of opportunistic microorganisms (S. saprophyticus, S. epidermidis) - $22 \%$. However, at chronic generalized periodontitis, the opportunistic associations prevailed.

A high degree of antibiotic resistance in the microorganisms isolated from the inflammatory process foci with generalized periodontitis was shown $-48 \%$ of isolates were resistant to at least 7 antibiotics. Thus, 3 isolates of $K$. rhinoskleromatis were resistant to 30 antibiotics. All the isolates were resistant to ampicillin, erythromycin, tetracycline.

The study results on the isolates' antibiotic susceptibility showed that $57.65 \%$ of isolates were susceptible to amoxicillin/clavulanate, $5.3 \%$ were moderately sensitive and $37.05 \%$ were resistant.

Isolates in the amount of $85.29 \%$ showed resistance to cephalosporins of the 1 st generation. Sensitivity to cephalosporins of the second generation has been established: to ceftriaxone $-61.76 \%$ and to cefuroxime $-55.29 \%$ of cultures. It was shown that $97 \%$ of isolates were susceptible to cefoperazone/sulbactam.

It was established that $73 \%$ of all isolates were susceptible to fluoroquinolones, in particular to fluoroquinolones of the second generation: to ofloxacin $-41.76 \%$ of isolates; to norfloxacin $-68.23 \%$; to lomefloxacin - $32.35 \%$; to ciprofloxacin $-68.82 \%$; to fluoroquinolones of the third generation: to levofloxacin $-75.29 \%$, and to the forth generation fluoroquinolones (gatifloxacin) - $87 \%$.

The opportunistic microorganisms were susceptible to the cabopenems: $80 \%-$ to meropenem and $58.23 \%$ - to imipenem.

Of the 170 isolates, $15.29 \%$ were sensitive to azithromycin, $30 \%$ were moderately susceptible and $55.29 \%$ were resistant. $30 \%$ of cultures were sensitive to the semisynthetic clarithromycin macrolides.

The microscopic Candida genus fungi was resistant to fluconazole, 6 strains showed sensitivity to itraconazole, 10 - to clotrimazole.

The conducted studies have shown that Dexasan antiseptic exhibited a wide spectrum of antimicrobial activity (see Figure). In particular, the sensitivity of all bacteria involved in the experiment as clinical isolates and typical cultures has been established. The highest levels of antimicrobial activity were recorded for the Staphylococcus genus bacteria, including methicillin-resistant strains. However, the antimycotic action of Dezasan on Candida species in the drug dose selected by us was not detected.

High antibacterial effect was observed as a result of the Dioxydine action, but the parameters of growth retardation zones varied greatly from $30.33 \pm 0.58 \mathrm{~mm}$ to the clinical strain of $S$. aureus to $17.33 \pm 0.33^{\circ}$ to $S$. aureus MRSA. High antibacterial activity of dioxydine on S. pneumonia has also been established. The bactericidal activity of the drug against $E$. faecalis and $K$. rhinoscleromatis was not detected. Moderate activity of the dioxydine against $E$. coli has been established.

The moderate sensitivity of the Staphylococcus genus bacteria to chlorhexidine is shown, but it is much lower than that of Dioxydine and Dexasane. Chlorhexidine did not affect methicillin-resistant $S$. aureus, and no antibacterial effect of chlorhexidine on the Streptococcus genus bacteria was detected.

ISSN 1996-4536 (print) • ISSN 2311-0783 (on-line) • Біологічні Студії / Studia Biologica • 2020 • Том 14/№1 • С. 51-62 


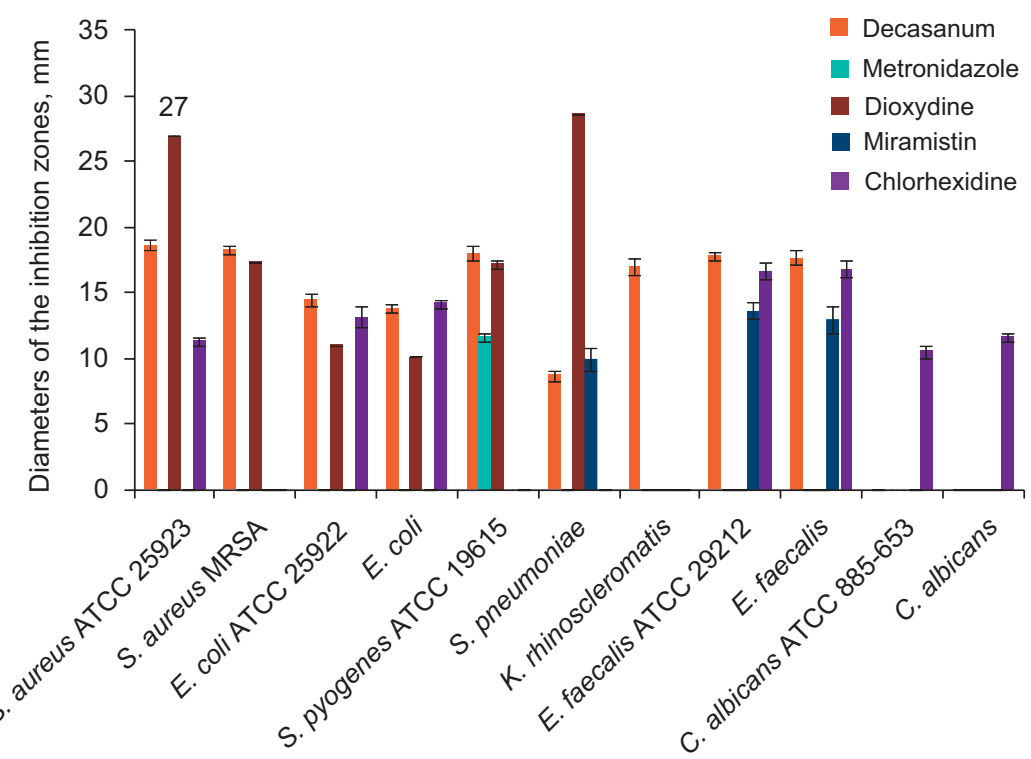

Antimicrobial activity of antiseptics and antibacterial preparations toward typical and clinical isolates of microorganisms

Антимікробна активність антисептиків і антибактеріальних препаратів на типові та клінічні ізоляти мікроорганізмів

Sensitive to chlorhexidine were E. faecalis and E. coli, however, K. rhinoscleromatis was not susceptible to the above antiseptic. The antimycotic effect of the chlorhexidine is shown. E. faecalis, S. pneumonia, S. viridans exhibited a moderate sensitivity to miramistin. Moderate antibiotic activity of metronidazole with S. pyogenes ATCC 19615 is shown.

The studies have shown a high level of the antimicrobial activity of the Sangviritrin drug, possessing a high antibacterial effect on Gram-positive microorganisms, a moderate effect on Gram-negative bacteria and a weak antimycotic activity (Table 1, Table 2). The Chlorophyllipt phytopreparation demonstrated high in vitro efficacy towards the Staphylococcus genus bacteria, more towards typical strains than to clinical ones, and to $E$. faecalis, weak and moderate activity towards E. coli.

The Eucalyptus tincture showed a high and moderate activity towards the isolates. No antimicrobial activity of the Mint rinse was detected, and low and moderate activity of the "Salvia" tincture towards the Staphylococcus and Streptococcus genera bacteria was observed. The Rotocanum drug produced a moderate and low antimicrobial effect on isolates involved in the experiment, except for E. coli and S. aureus (MRSA).

At chronic persistent inflammatory process, the opportunistic microorganisms dominate in the oral cavity of patients with generalized periodontitis.

The obtained results are consistent with the data of other researchers [8] who established the domination of the Staphylococcus genus bacteria in the microbiota of the oral cavity in patients with generalized periodontitis. The authors also identify the S. aureus, S. epidermidis, Bacteroides spp., Actinomyces spp., Candida spp., Pseudomonas aeruginosa and Streptococcus spp. microorganisms, as the most important agents 
Table 1. Results of study of the commercial phytopreparations antimicrobial activity towards typical strains, $\mathrm{mm},(\bar{x} \pm s)$

Таблиця 1. Результати дослідження антимікробної активності комерційних фітопрепаратів на типові штами, мм, $(\bar{x} \pm s)$

\begin{tabular}{l|c|c|c|c|c}
\hline \multicolumn{1}{|c|}{ Test-culture } & Sangviritrin & Chlorophyllipt & $\begin{array}{c}\text { Tinctura } \\
\text { Salviae }\end{array}$ & Rotocanum & $\begin{array}{c}\text { Tinctura } \\
\text { Eucalypti }\end{array}$ \\
\hline $\begin{array}{l}\text { Staphylococcus aureus } \\
\text { ATCC 25923 }\end{array}$ & $26.33 \pm 0.58^{\mathrm{b}}$ & $25.00 \pm 1.00^{\mathrm{b}}$ & $7.83 \pm 0.28^{\mathrm{b}}$ & $10.33 \pm 0.57^{\mathrm{b}}$ & $16.33 \pm 0.57^{\mathrm{b}}$ \\
$\begin{array}{l}\text { Streptococcus } \\
\text { pyogenes ATCC } 19615\end{array}$ & $31.30 \pm 0.58^{\mathrm{a}}$ & - & $9.00 \pm 0.1^{\mathrm{a}}$ & $12.33 \pm 0.58^{\mathrm{a}}$ & $15.83 \pm 0.58^{\mathrm{b}}$ \\
$\begin{array}{l}\text { Escherichia coli } \\
\text { ATCC 25922 }\end{array}$ & $24.66 \pm 0.57^{\mathrm{c}}$ & $15.33 \pm 0.57^{\mathrm{c}}$ & - & $8.33 \pm 0.57^{\mathrm{c}}$ & $14.33 \pm 0.58^{\mathrm{c}}$ \\
$\begin{array}{l}\text { Enterococcus faecalis } \\
\text { ATCC 29212 }\end{array}$ & $26.17 \pm 0.58^{\mathrm{b}}$ & $28.66 \pm 0.57^{\mathrm{a}}$ & - & $13.66 \pm 0.57^{\mathrm{a}}$ & $21.83 \pm 0.58^{\mathrm{a}}$ \\
$\begin{array}{l}\text { Candida albicans } \\
\text { ATCC 885-653 }\end{array}$ & $13.33 \pm 1.15^{\mathrm{d}}$ & - & - & $8.33 \pm 0.57^{\mathrm{c}}$ & $14.16 \pm 0.29^{\mathrm{c}}$ \\
\hline
\end{tabular}

Comment: data in the column followed by different letters are reliably different at $P<0.05$ according to Tukey's HSD test; "-" - no inhibition

Примітка: дані у стовпці, позначені різними літерами, достовірно відрізняються за $\mathrm{P}<0,05$ згідно з Тукі тестом; "-" - затримки росту немає

Table 2. Results of study of the commercial phytopreparations antimicrobial activity towards clinic strains, $\mathrm{mm},(\bar{x} \pm s)$

Таблиця 2. Результати дослідження антимікробної активності комерційних фітопрепаратів на клінічні штами, мм, $(\bar{x} \pm s)$

\begin{tabular}{l|c|c|c|c|c}
\hline \multicolumn{1}{|c|}{ Test-culture } & Sangviritrin & Chlorophyllipt & $\begin{array}{c}\text { Tinctura } \\
\text { Salviae }\end{array}$ & Rotocanum & $\begin{array}{c}\text { Tinctura } \\
\text { Eucalypti }\end{array}$ \\
\hline $\begin{array}{l}\text { Staphylococcus aureus } \\
\text { (MRSA) }\end{array}$ & $21.33 \pm 0.58^{\mathrm{b}}$ & $15.33 \pm 0.58^{\mathrm{b}}$ & - & - & $13.66 \pm 0.76^{\mathrm{d}}$ \\
\hline $\begin{array}{l}\text { Staphylococcus } \\
\text { haemolyticus }\end{array}$ & $24.66 \pm 0.57^{\mathrm{a}}$ & $16.33 \pm 0.58^{\mathrm{b}}$ & $8.66 \pm 0.57^{\mathrm{a}}$ & $9.33 \pm 0.58^{\mathrm{b}}$ & $15.50 \pm 0.50^{\mathrm{b}}$ \\
\hline $\begin{array}{l}\text { Streptococcus viridans } \\
\text { Streptococcus }\end{array}$ & $15.33 \pm 0.58^{\mathrm{d}}$ & - & $8.83 \pm 0.58^{\mathrm{a}}$ & $13.33 \pm 0.58^{\mathrm{a}}$ & $20.33 \pm 0.57^{\mathrm{a}}$ \\
\hline $\begin{array}{l}\text { pneumonia } \\
\text { Escherichia coli }\end{array}$ & $20.00 \pm 1.00^{\mathrm{c}}$ & - & $8.66 \pm 0.57^{\mathrm{a}}$ & $12.33 \pm 0.58^{\mathrm{a}}$ & $12.66 \pm 1.52^{\mathrm{d}}$ \\
\hline $\begin{array}{l}\text { Klebsiella } \\
\text { rhinoscleromatis }\end{array}$ & $19.66 \pm 0.58^{\mathrm{c}}$ & $14.33 \pm 0.57^{\mathrm{bc}}$ & - & - & $15.17 \pm 1.26^{\mathrm{b}}$ \\
\hline $\begin{array}{l}\text { Enterococcus faecalis } \\
\begin{array}{l}\text { Candida albicans } \\
\text { ATCC 885-653 }\end{array}\end{array}$ & $20.17 \pm 0.17^{\mathrm{c}}$ & $23.33 \pm 0.57^{\mathrm{a}}$ & - & $12.50 \pm 0.50^{\mathrm{a}}$ & $20.66 \pm 0.57^{\mathrm{a}}$ \\
$\begin{array}{l}\text { Candida albicans } \\
\text { (clinic) }\end{array}$ & $13.33 \pm 1.15^{\mathrm{e}}$ & - & - & $8.33 \pm 0.57^{\mathrm{c}}$ & $14.16 \pm 0.29^{\mathrm{cd}}$ \\
\hline
\end{tabular}

Comment: data in the column followed by different letters are reliably different at $P<0.05$ according to Tukey's HSD test; "-"- no inhibition

Примітка: дані у стовпці, позначені різними літерами, достовірно відрізняються за $\mathrm{P}<0,05$ згідно з Тукі тестом; "-" - затримки росту немає

ISSN 1996-4536 (print) • ISSN 2311-0783 (on-line) • Біологічні Студії / Studia Biologica • 2020 • Том 14/№1 • С. 51-62 
causing the development of generalized periodontitis and the role of the above microorganisms proteolytic enzymes, including collagenolytic enzymes, hyaluronidase, chondroitin sulfatase in the disintegration of collagen, the main protein of the periodontal tissue. The authors also report high sensitivity of the opportunistic microbiota to clindamycin and ofloxacin.

Other authors reported about the domination of the Streptococcus spp., Staphylococcus spp., Kocuria spp., Enterobacter spp. genera representatives and of the Candida spp. genus yeast-like fungi in the periimplant region of patients with mucositis. All isolates demonstrated sensitivity to fluoroquinolones and were resistant to penicillins, macrolides, lincosamines, that coincided with our results [5].

Colonization of the oral cavity with pathogenic bacteria can be an antecedent and, in its turn, can lead to other diseases [1]. Diseases of the periodontal tissues contribute to the oropharyngeal colonization by potential respiratory pathogens, including Enterobacteriaceae (K. pneumoniae, E. coli, Enterobacter sp., P. aeruginosa, and $S$. aureus).

The persistence of opportunistic microorganisms in the oral cavity creates preconditions for the development of systemic diseases, especially, this correlation is established in the elderly persons [1, 2].

The domination of opportunistic microorganisms in the oral cavity in conditions of generalized periodontitis causes the need for antibacterial therapy. The literature data report that according to the dental practitioners' survey, amoxicillin $(73.58 \%)$ is the most frequently prescribed as an antibiotic systemic treatment, $36.47 \%$ of dentists recommend lincomycin to patients, and fluoroquinolone preparations (ciprofloxacin) are prescribed by $30.18 \%$ of dental practitioners, doxycycline - by $17.61 \%$, clarithromycin by $5.03 \%$ [1]. Our studies showed high sensitivity of the opportunistic microorganisms, isolated from the inflammatory foci, to fluoroquinolones, however, their high resistance to penicillins, macrolides, lincomycin, doxycycline was established.

It is shown that most microorganisms causing complications of dental implantation are resistant to penicillins, macrolides, lincosamines [2]. A significant increase in the level of antibiotic resistant strains of microorganisms in conditions of periodontal inflammatory diseases, may be due to the presence of bacteria in the composition of biofilm. It has been proved that the resistance of bacteria to antibiotics within the biofilm is several orders greater $[4,6,11,17]$.

At the same time, the auxiliary or alternative means of the opportunistic microbiota correction is the use of local antiseptics and phytopreparations to potentiate the action of antibiotics, and in benign cases, an alternative to their application [5, 8]. We have established low efficacy of the antimycotic drugs, particularly their local effects. Meanwhile, in our previous studies, high activity of essential oils $[9,10,16]$ and phytopreparations to isolates of opportunistic infections pathogens, including microscopic fungi of the Candida genus was established.

\section{CONCLUSION}

At generalized periodontitis, the domination of conditionally pathogenic microorganism associations in the microbiote of the oral cavity was observed. Association of the bacteria of Staphylococcus genus and Enterobacteriaceae family accompanied the most complex recurrent inflammatory processes. High percentage of the antibiotic resistant isolates is shown.

ISSN 1996-4536 (print) • ISSN 2311-0783 (on-line) • Біологічні Студії / Studia Biologica • 2020 • Том 14/№1 • С. 51-62 
It was found that the most effective against the isolates were fluoroquinolones and cefoperazone/sulbactam. Among antiseptics, Decasanum demonstrated a wide range of the antibacterial activity. The high antimicrobial effect was demonstrated by Sangviritrin.

The application of a comprehensive, differential approach to the correction of microbiota in the oral cavity at generalized periodontitis is grounded. Taking into account the dominant associations and their sensitivity to antibacterial drugs, including phytopreparations, which, in addition to antimicrobial activity, do not violate the composition of the indigenous microbiota.

\section{ACKNOWLEDGMENTS}

The present study is a fragment of the research project at the Department of Genetics, Plant Physiology and Microbiology of Uzhhorod National University "Research of genetic, physiological and biochemical mechanisms of various organization level biological systems adaptation in the anthropogenic loading conditions", No. 0115 U003902.

\section{COMPLIANCE WITH ETHICAL STANDARDS}

Conflict of Interest: The authors declare that the research was conducted in the absence of any commercial or financial relationships that could be construed as a potential conflict of interest.

Animal Rights: This article does not contain any studies with animal subjects performed by the any of the authors.

1. Al Jehani Y.A. Risk factors of periodontal disease: review of the literature. International Journal of Dentistry, 2014; $1-9$.

[DOI: http://dx.doi.org/10.1155/2014/182513; PMid: 24963294; Google Scholar]

2. Assaf A.M., Amro B.I., Mashallah S., Haddadin R.N. Antimicrobial and anti-inflammatory potential therapy for opportunistic microorganisms. The Journal of Infection in Developing Countries, 2016; 10(05): 494-505.

[DOI: http://dx.doi.org/10.3855/jidc.7610; PMid: 27249525; Google Scholar]

3. Balouiri M., Sadik M., Ibn Souda S.K. Methods for in vitro evaluating antimicrobial activity: A review. Journal of Pharmaceutical Analysis, 2016; 6(2): 71-79.

[DOI:http://dx.doi.org/10.1016/j.jpha.2015.11.005; PMid: 29403965; Google Scholar]

4. Cazzaniga A., Galli C., Fiorini A., Cantini E., Lodi G. Systemic antibiotics as adjunctive treatment for chronic periodontitis. Cochrane Database of Systematic Reviews, 2005; 1: Art. No.: CD005099.

[DOI: http://dx.doi.org/10.1002/14651858.cd005099; Google Scholar]

5. Faustova M.O. Sensitivity of dominant pathogens of infectious and inflammatory complications after dental implantation to antibiotics and antiseptics. Annals of Mechnikov Institute, 2017; 2: 68.

6. Fluit A., Schmitz F., Verhoef J. Multi-resistance to antimicrobial agents for the ten most frequently isolated bacterial pathogens. International Journal of Antimicrobial Agents, 2001; 18(2): 147-60.

[DOI: https://doi.org/10.1016/S0924-8579(01)00357-0; Google Scholar]

7. Jakobi M., Stumpp S., Stiesch M., Eberhard J., Heuer W. The Periimplant and periodontal microbiota in patients with and without clinical signs of inflammation. Dentistry Journal, 2015; 3(2): 24-42.

[DOI: http://dx.doi.org/10.3390/dj3020024; PMid: 29567923; Google Scholar]

ISSN 1996-4536 (print) • ISSN 2311-0783 (on-line) • Біологічні Студії / Studia Biologica • 2020 • Том 14/№1 • C. 51-62 
8. Krisenko O.V., Sklyar T.V., Voronkova O.S., Sirokvasha O.A., Shevchenko T.M. Features of microbial assotiation composition an antibioticresistence of oral cavity microflora. Microbiology \& Biotechnology. 2014; 1(25): 35-44.

[DOI: https://doi.org/10.18524/2307-4663.2014.1(25).48199; Google Scholar]

9. Kryvtsova M. V., Kostenko Ye. Ya., Salamon I. Compositions of essential oils with antimicrobial properties against isolates from oral cavities of patients with inflammatory diseases of parodentium. Regulatory Mechanisms in Biosystems, 2018; 9(4): 491-4. [DOI: https://doi.org/10.15421/021873; Google Scholar]

10. Kryvtsova M.V., Trush K., Eftimova J., Koščová, J., Spivak M.J. Antimicrobial, antioxidant and some biochemical properties of Vaccinium vitis-idea L. Mikrobiolohichnyi Zhurnal, 2019; 3: 40-52.

[DOI: https://doi.org/10.15407/microbiolj81.03.040; Google Scholar]

11 Liljemark W. F., Bloomquist C. Human oral microbial ecology and dental caries and periodontal diseases. Critical Reviews in Oral Biology Medicine, 2016; 2(7): 180-198. [DOI: https://doi.org/10.1177/10454411960070020601; PMid: 8875032; Google Scholar]

12. Mazur I., Stavska D., Gelashvili L. The usage of pharmaceutical drugs in dentistry. Sovremennaya Stomatologiya, 2016; 2: 24-27. (In Russian)

[Google Scholar]

13. Noiri Y., Ehara A., Kawahara T., Takemura N., Ebisu S. Participation of bacterial biofilms in refractory and chronic periapical periodontitis. Journal of Endodontics, 2002; 10 (28): 679-683.

[DOI: https://doi.org/10.1097/00004770-200210000-00001; PMID: 12398163; Google Scholar]

14. Pérez-Chaparro P. J, Gonçalves C., Figueiredo L.C., Faveri M., Lobão E., Tamashiro N., Duarte P., Feres M. Newly identified pathogens associated with periodontitis: a systematic review. J Dent Res, 2014; 93(9): 1-13.

[DOI: https://doi.org/10.1177/0022034514542468; PMid: 25074492; Google Scholar]

15. Ricucci D., Siqueira J. F. Jr. Biofilms and apical periodontitis: study of prevalence and association with clinical and histopathologic findings. Journal of Endodontics, 2010; 8 (36): 1277-1288.

[DOI: https://doi.org/10.1016/j.joen.2010.04.007; PMid: 20647081; Google Scholar]

16. Salamon I., Kryvtsova M., Bucko D., Tarawneh Amer H. Chemical characterization and antimicrobial activity of some essential oils after their industrial large-scale distillation. The Journal of Microbiology, Biotechnology and Food Sciences, 2018; 8(3): 965-969.

[DOI: http://dx.doi.org/10.15414/jmbfs.2018.8.3.965-969; Google Scholar]

17. Schindel L. Antibiotic-resistant bacteria. Unexpected Reactions to Modern Therapeutics, 2013; 94-101.

[DOI: https://doi.org/10.1016/B978-1-4831-6673-5.50010-8; Google Scholar]

18. Tada A., Senpuku H., Motozawa Y., Yoshihara A., Hanada N., Tanzawa H. Association between commensal bacteria and opportunistic pathogens in the dental plaque of elderly individuals. Clinical Microbiology and Infection, 2006; 12(8): 776-781.

[DOI: https://doi.org/10.1111/j.1469-0691.2006.01497.x; PMID: 16842573; Google Scholar]

ISSN 1996-4536 (print) • ISSN 2311-0783 (on-line) • Біологічні Студії / Studia Biologica • 2020 • Том 14/№1 • C. 51-62 


\title{
ДОМІНУЮЧІ МІКРОБНІ АСОЦІАЦІЇ РОТОВОЇ ПОРОЖНИНИ В УМОВАХ ПАРОДОНТИТУ Й ОСОБЛИВОСТІ ЇХНЬОЇ ЧУТЛИВОСТІ ДО АНТИБАКТЕРІАЛЬНИХ ПРЕПАРАТІВ
}

\author{
М. В. Кривцова ${ }^{1 *}$, Є. Я. Костенко \\ 1 Ужгородський національний університет \\ біологічний фракультет, кафредра генетики, фрізіології рослин і мікробіології \\ вул. Волошина, 32, Ужгород 88000, Україна \\ 2 Ужгородський національний університет \\ стоматологічний фракультет, кафредра ортопедичної стоматології \\ вул. Університетська, 16, Ужгород 88000, Україна \\ *Кореспондуючий автор: e-mail: maryna.krivcova@uzhnu.edu.ua
}

Умовно-патогенні мікроорганізми відіграють значну роль у розвитку запальних захворювань, зокрема, генералізованого пародонтиту. Персистенція представників алохтонної мікробіоти у ротовій порожнині хворих із генералізованим пародонтитом створює передумови для ускладнення основного захворювання та потребує застосування антибактеріальних препаратів. Нераціональне використання антимікробних препаратів призводить до поширення резистентних мікроорганізмів. Саме зростаюча тенденція до фрормування антибіотикорезистентності визначає актуальність моніторингу чутливості мікроорганізмів до антимікробних препаратів і розробки нових підходів до антимікробної терапії. Важливим фрактором успішного застосування препаратів з антимікробною активністю $є$ постійний моніторинг чутливості мікроорганізмів до антибіотиків і антисептиків, які використовуються у стоматології. Крім того, особливу увагу привертають місцеві антисептики, які застосовувались у вигляді аплікацій, пародонтальних пов'язок, іригацій тощо. Метою роботи було визначити домінуючі мікробні асоціації ротової порожнини в умовах генералізованого пародонтиту, дослідити їхню чутливість до антибіотиків, антисептиків і фрітопрепаратів. Вивчення мікробних асоціацій в умовах генералізованого пародонтиту проводили способом бактеріологічного дослідження патологічного матеріалу з вогнища запального процесу. Забір біологічного матеріалу зі слизової оболонки осередку запального процесу проводили за допомогою стерильної транспортної системи (пробірка з гелем і аплікатором для біологічних рідин виробництва FLmedical) (Italy). Матеріал висівали на диференційно діагностичні поживні середовища. Визначення антибіотикочутливості ізолятів проводили дискодифузійним методом, до антисептиків і фрітопрепаратів - методом дифузії в агар. Дослідженням встановлено, що умовно-патогенні мікроорганізми у 100 \% випадків домінували у складі мікробіоти ротової порожнини хворих на генералізований пародонтит. Найчіткіші клінічні симптоми захворювання і рецидивування запального процесу спостерігали у разі персистенції в ротовій порожнині асоціації бактерій роду Staphylococcus із бактеріями родини Enterobacteriaceae роду Pseudomonas, мікроскопічними грибами роду Candida. Персистенція умовно патогенних бактерій у ротовій порожнині хворих із генералізованим пародонтитом створює передумови для ускладнення основного захворювання та потребує застосування антибактеріальних препаратів. З'ясовано високий ступінь антибіотикорезистентності мікроорганізмів, ізольованих із осередків запального процесу в разі генералізованого паро-

ISSN 1996-4536 (print) •ISSN 2311-0783 (on-line) • Біологічні Студії / Studia Biologica • 2020 • Том 14/№1 • C. 51-62 
донтиту, зокрема, 48 \% ізолятів були стійкими як мінімум до 7 антибіотиків. Умовно-патогенні мікроорганізми були чутливими до кабопенемів: 80 \% ізолятів до меропенему та 58,23 \% іміпенему. Встановлено високий рівень стійкості до азитроміцину: зі 180 ізолятів 15,29 \% були чутливими до азитроміцину, 30 \% помірно чутливими та 55,29 \% резистентними. Виявлено, що найефективнішими щодо ізолятів були фторхінолони і цефоперазон/сульбактам. 3 антисептиків Декасан виявляв широкий спектр антибактеріальної активності. Зокрема, встановлено чутливість усіх взятих в експеримент бактерій як клінічних ізолятів, так і типових культур. Найвищий рівень антимікробної активності реєстрували щодо бактерій роду Staphylococcus, зокрема, метицилін резистентний штам. Декасан виявляв активність до клінічних поліантибіотикорезистентних штамів Klebsiella spp. Проте антимікотичної дії Декасану на гриби роду Candida в обраній нами дозі препарату не виявлено. 3'ясовано помірну чутливість бактерій роду Staphylococcus до хлоргексидину, проте значно нижчу, ніж Діоксидину та Декасану. Хлоргексидин не впливав на метицилінрезистентний S. aureus. Не виявлено антибактеріальної дії хлоргексидину щодо бактерій роду Streptococcus, встановлено також його антимікозний ефект. До Мірамістину виявляли помірну чутливість Enterococcus faecalis, Streptococcus pneumonia, Streptococcus viridans. Дослідженням виявлено високий рівень антимікробної активності препарату Сангвіритрин, який мав значний антибактеріальний ефект на грампозитивні мікроорганізми, помірну дію на грамнегативні бактерії та слабку антимікозну активність. Фіторепарат Хлорофріліпт показав високу in vitro ефрективність на бактерії роду Staphylococcus, більшою мірою на типові штами, ніж на клінічні; слабку та помірну активність щодо E. coli. Препарат Ротокан виявляв помірну та низьку антимікробну дію на ізоляти, взяті в експеримент, і не впливав на E. coli та S. aureus (MRSA). Встановлені закономірності визначають актуальність проведення антибактеріальної терапії з урахуванням антібіотикочутливості збудників запального процесу і розробки комплексного підходу до корекції умовно-патогенної мікробіоти в умовах генералізованого пародонтиту.

Ключові слова: антибіотикорезистентні ізоляти, опортуністичні мікроорганізми, антибактеріальна активність, мікробіота ротової порожнини 